\title{
Atomoxetine: a new pharmacotherapeutic approach in the management of attention deficit/hyperactivity disorder
}

\author{
J Barton
}

Arch Dis Child 2005;90(Suppl I):i26-i29. doi: 10.1136/adc.2004.059386

Atomoxetine is a novel, non-stimulant, highly selective noradrenaline reuptake inhibitor that has been studied for use in the treatment of attention deficit/hyperactivity disorder (ADHD). Data from clinical trials show it to be well tolerated and effective in the treatment of ADHD in children, adolescents, and adults. Improvements were seen not only in core symptoms of $A D H D$, but also in broader social and family functioning and self esteem. Once-daily dosing of atomoxetine has been shown to be effective in providing continuous symptom relief. Atomoxetine does not appear to have abuse potential and is associated with a benign side effect profile. The development of atomoxetine thus represents an important advance in the pharmacological management of ADHD.

Correspondence to:

Dr J Barton, North

Staffordshire Combined Health Care NHS Trust, Moorlands Team, Abbey Hulton Clinic, Leek Road, Stoke-On-Trent,

Staffordshire ST2 8BP, UK; Joanne.Barton@nsch-tr. wmids.nhs.uk
$\mathrm{P}$ harmacotherapy is an important component of the multimodal management of attention deficit/hyperactivity disorder (ADHD), but currently this approach is restricted by the limited range of licensed drugs. Management to date has been dominated by the use of the psychostimulants methylphenidate and dexamfetamine, for which there is a substantial evidence base describing their efficacy. ${ }^{1}$ Although the range of formulations of psychostimulants has increased over the years to include long acting and continuous release formulations, their use is limited by their duration of action, problematic adverse effects, abuse potential, and reluctance on the part of some children and families to take controlled drugs. A range of other drugs including tricyclic antidepressants, venlafaxine, guanfacine, and clonidine are also used in the management of ADHD; however, the evidence base for their effectiveness is less extensive than that for the psychostimulants and none are licensed for this purpose. ${ }^{2}$

The focus of treatment to date has been on the relief of the core symptoms of ADHD. However, there is an increasing awareness of the need to address not only the immediate control of symptoms, but also broader treatment goals encompassing the quality of life of the affected individual and their family. The nature of ADHD is such that effects can be pervasive, adversely affecting school, home, and social life. It is associated with adverse outcome in terms of poor peer and family relationships and academic underachievement. ${ }^{3}$ ADHD can persist through childhood and adolescence into adult life, with implications for affected individuals across their lifespan including a potential requirement for lifelong treatment. ${ }^{4}$ Because of the limitations of existing treatments and the paradigm shift in thinking about the management of ADHD, there is an interest in the development of new pharmacological treatments.

\section{ATOMOXETINE HYDROCHLORIDE: A NOVEL TREATMENT FOR ADHD}

Atomoxetine is the first non-stimulant to be approved for the treatment of ADHD and the first drug to be licensed for the treatment of ADHD in adults. ${ }^{5}$ Atomoxetine was licensed in the US in November 2002 and in the UK in May 2004. At the time of writing, it is under consideration for licensing by the regulatory authorities in a number of other countries.

\section{Clinical pharmacology}

The neurobiological evidence suggests that drugs that have an effect on dopamine and noradrenaline may have therapeutic potential in ADHD. ${ }^{6}$ Atomoxetine (chemical designation: benzenepropanamine; (-)-N-methyl-3-phenyl-3-(o-tolyloxy)-propylamine hydrochloride; molecular formula: $\mathrm{C}_{17} \mathrm{H}_{21} \mathrm{NOHCl}$ ) (fig l) affects the regulation of noradrenaline. It is a highly selective inhibitor of the presynaptic noradrenaline transporter with little or no affinity for other neurotransmitter transporters and receptors. It increases the availability of extracellular noradrenaline in the prefrontal cortex and also increases dopamine levels in this region, but not in the nucleus accumbens or the striatum. ${ }^{7}$ This mechanism of action suggests that atomoxetine is unlikely to have abuse potential or to cause motor tics. ${ }^{78}$

Atomoxetine is rapidly absorbed after oral administration and can be taken with or without food. Peak plasma levels are reached 1-2 hours after ingestion. Atomoxetine is metabolised by the majority of the general population through the cytochrome P450 2D6 pathway, 5-10\% metabolise it more slowly through a combination of cytochrome P450 and 2D6 enzymes. ${ }^{9}$ The half life of atomoxetine is 5.2 hours in rapid metabolisers and 21.6 hours in slow metabolisers, but metaboliser status does not affect dose, dose schedule, or side effect profile. ${ }^{10}$ Atomoxetine is mainly excreted in the urine $(80 \%)$ with the remainder being passed in the faeces. Atomoxetine does not appear to induce or inhibit the cytochrome P450 2D6 enzyme system, but other medications that do (for example, paroxetine) increase the availability of atomoxetine. ${ }^{11}$ In vivo studies indicate that atomoxetine administration with substrates of CYP2D6 and CYP3A does not result in clinically significant drug interaction. ${ }^{12}$ Co-administration of atomoxetine 


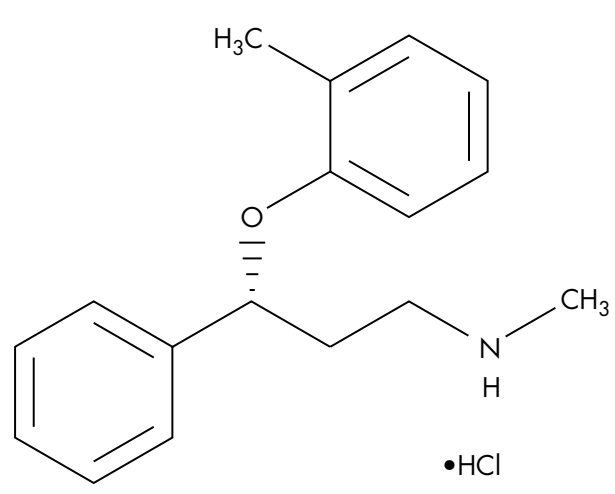

Figure 1 Structure of atomoxetine.

with desipramine, a model compound for drugs metabolised by CYP2D6, did not alter the plasma pharmacokinetics of atomoxetine or desipramine. Similarly, co-administration of atomoxetine with midazolam, a model compound for CYP3A metabolised drugs, resulted in only a minor statistically insignificant increase in midazolam plasma exposure. ${ }^{12}$

The effects of atomoxetine seem to last longer than would be expected from its pharmacokinetics in that once-daily administration is effective, with behavioural control continuing after the drug has apparently been cleared from the plasma. ${ }^{13}$ The reasons for this are not clear, but may be explained by differences in brain and plasma pharmacokinetics or by continued effects on the noradrenaline transporter.

\section{Clinical studies}

The efficacy of atomoxetine in ADHD was first examined in adults in a double blind, placebo controlled study, the results of which demonstrated its superiority over placebo in reducing ADHD symptoms and that it was well tolerated. ${ }^{14}$ This was followed by an open label pilot study and a dose ranging study in children and young people, both of which were positive in demonstrating efficacy and tolerability. ${ }^{15} 16$

An extensive clinical trials programme has been designed to investigate the detail of atomoxetine's therapeutic potential. As part of this programme, eight paediatric randomised, double blind, placebo controlled trials of efficacy have been published to date (table 1).

In all of the studies (adult and child) subjects had to meet Diagnostic and Statistical Manual of Mental Disorders (DSM) criteria for ADHD. Exclusion criteria included having comorbid diagnoses with major depression, marked anxiety or history of bipolar depression or psychosis, major physical illness, alcohol abuse, active use of illicit drugs, or having an IQ of less than 75 . In the adult studies, ${ }^{14}{ }^{17}$ subjects must have presented with DSM-III-R defined ADHD before the age of 7 years and experienced ongoing ADHD symptoms with evidence of impairment. In the child studies, inclusion was based on evidence of DSM-IV defined ADHD on clinical history, confirmed by the Kiddie Schedule for Affective Disorders and Schizophrenia (K-SADS). ${ }^{18}$ The primary outcome measures in the child and adolescent studies were the ADHD Rating Scale (ADHD-RS) ${ }^{19}$ and the Clinical Global Impression of ADHD Severity (CGI-S).$^{20}$ In the adult studies, the Conners' Adult ADHD Rating Scale (CAARS) ${ }^{21}$ and the CGI-S were used. The use of the same primary outcome measures across studies facilitates comparison.

In all of the child and adult randomised, placebo controlled trials, atomoxetine was significantly superior to placebo in the treatment of ADHD. ${ }^{122} 23$ Both inattention and hyperactive/impulsive symptoms improved significantly with treatment. In some of the paediatric studies, parent and teacher versions of the Conners' questionnaires ${ }^{24}$ were completed, and here again significant improvements in ADHD total and subscale scores were achieved. ${ }^{13}$

Whereas a reduction in symptoms is measurable within one week of assignment to atomoxetine, near maximal efficacy is approached by approximately four weeks. ${ }^{13} 23$ Atomoxetine demonstrates efficacy comparable to methylphenidate in the treatment of ADHD, as established in a 10 week, open label study. ${ }^{10}$ Among children with DSM-IV defined ADHD, similar reductions in ADHD symptoms were seen in both the atomoxetine and methylphenidate treatment groups. Safety and tolerability were also similar for the two drugs.

A six week, randomised, double blind, placebo controlled trial in children confirmed the observation that the duration of action of atomoxetine is longer than the five hour blood half life would otherwise indicate, and that once-daily dosing is effective in providing continuous symptom relief. ${ }^{13}$ The beneficial effects of atomoxetine were observed until the evening and settling at bedtime. ${ }^{13}$ In addition, a study by Kelsey et $a^{25}$ showed that once-daily atomoxetine administration in the morning was associated with continuous symptom relief not only into the evening, but also into the following morning. Dose response in adults was found to be similar to that in children. ${ }^{17} \mathrm{~A}$ recent international study has confirmed the effectiveness of atomoxetine in non-North American children and young people. ${ }^{26}$

The clinical trials programme has examined in a preliminary way the broader efficacy of atomoxetine with secondary outcome measures addressing effects on comorbidities including anxiety, depression, and oppositional defiant disorder. Although studies have not been sufficiently powered to provide definitive evidence for efficacy they do indicate that atomoxetine may have beneficial effects in these areas. $^{8}{ }^{16}$ Broader social and family functioning has been assessed in two studies using the Child Health Questionnaire (CHQ), a parent rated health outcome scale that measures physical and psychosocial wellbeing. Michelson et al found that improvements in social and family functioning and self esteem were superior among atomoxetine treated patients compared with those in the placebo group. The 24 hour continuous symptom relief offered by atomoxetine, with the resulting treatment benefits during school time, family hours, and sleep may create a significantly greater potential for psychosocial improvements to child and family.

Although all of the studies were consistent in demonstrating the effectiveness of atomoxetine, a few limitations exist. In particular, there is a lack of data relating to the long term outcome of trials beyond nine weeks, although longer term data are emerging. ${ }^{27}$ In addition, limited information is available comparing atomoxetine to stimulants. ${ }^{1028}$

\section{Adverse effects and monitoring}

In general, atomoxetine has been shown to be well tolerated. Wernicke and Kratochvil ${ }^{29}$ reviewed data from clinical trials and found that the most common drug related events reported were decreased appetite and an initial period of weight loss, followed by an apparently normal rate of weight gain. Serious adverse events have not been associated with the drug, and there have been few discontinuations due to adverse events. No evidence of insomnia has been found. Side effects encountered significantly more frequently than with placebo include dizziness and dyspepsia. ${ }^{22}$ In general, side effects have been noted to be transient, occurring primarily during the initiation and titration of atomoxetine. ${ }^{29}$

Particularly encouraging are the benign cardiovascular findings associated with atomoxetine treatment. For both adults and children, administration of atomoxetine produced no effects on cardiac conduction, repolarisation, or rhythm, 
Table 1 Published atomoxetine clinical trials

\begin{tabular}{|c|c|c|c|c|}
\hline $\begin{array}{l}\text { Study design and } \\
\text { duration }\end{array}$ & Inclusion criteria & Exclusion criteria & Outcome measures & Author \\
\hline $\begin{array}{l}\text { Double blind, placebo } \\
\text { controlled in adults, } \\
3 \text { weeks }\end{array}$ & $\begin{array}{l}\text { DSM-III-R criteria by the age of } \\
7 \text { years }\end{array}$ & $\begin{array}{l}\text { Chronic medical conditions } \\
\mathrm{IQ}<75 \\
\text { Organic brain disorders } \\
\text { Active psychiatric conditions } \\
\text { History of drug or alcohol abuse } \\
\text { Pregnancy or nursing }\end{array}$ & $\begin{array}{l}\text { ADHD-RS; HDRS; HARS; } \\
\text { BDI }\end{array}$ & Spencer et al ${ }^{14}$ \\
\hline $\begin{array}{l}\text { Open label trial in } \\
\text { children; } 10 \text { weeks }\end{array}$ & DSM-IV & No information given & $\begin{array}{l}\text { ADHD Rating Scale IV - } \\
\text { parent version; } C G I ; \\
\text { CPRS-R:S }\end{array}$ & Kratochvil et al ${ }^{15}$ \\
\hline $\begin{array}{l}\text { Open label, dose } \\
\text { ranging study in } \\
\text { children; } 11 \text { weeks }\end{array}$ & DSM-IV & $\begin{array}{l}\text { Clinically significant medical conditions } \\
\text { Mental retardation; unstable psychiatric } \\
\text { condition } \\
\text { History of drug or alcohol abuse } \\
\text { Current use of psychotropic medication }\end{array}$ & $\begin{array}{l}\text { ADHD Rating Scale IV; } \\
\text { CGI; CPRS-R:S; ODD-RS }\end{array}$ & Spencer et al ${ }^{16}$ \\
\hline $\begin{array}{l}\text { Randomised, } \\
\text { placebo controlled, } \\
\text { dose response study } \\
\text { in children; } 8 \text { weeks }\end{array}$ & $\begin{array}{l}\text { DSM-IV; ADHD Rating Scale } \\
\text { IV - parent version }\end{array}$ & $\begin{array}{l}\text { Serious medical illness } \\
\text { Comorbid psychosis } \\
I Q<80 \text {. }\end{array}$ & $\begin{array}{l}\text { ADHD-RS; CPRS-R; } \\
\text { CDRS-R; CGI-S; CHQ }\end{array}$ & Michelson et $a l^{8}$ \\
\hline $\begin{array}{l}\text { Randomised, open } \\
\text { label trial in children; } \\
10 \text { weeks comparator } \\
\text { with methylphenidate }\end{array}$ & DSM-IV diagnostic criteria & $\begin{array}{l}\text { History of bipolar or psychotic disorders } \\
\text { Motor tics or family history of Tourette } \\
\text { syndrome } \\
\text { Substance abuse. }\end{array}$ & $\begin{array}{l}\text { ADHD RS (investigator } \\
\text { and parent rated); CPRS-R; } \\
\text { CGI }\end{array}$ & Kratochvil et al ${ }^{10}$ \\
\hline $\begin{array}{l}\text { Two randomised, } \\
\text { placebo controlled, } \\
\text { proof of concept } \\
\text { studies in children; } \\
12 \text { weeks }\end{array}$ & $\begin{array}{l}\text { DSM-IV diagnostic criteria; ADHD } \\
\text { Rating Scale IV - Parent: Investigator } \\
\text { Administered and Scored }\end{array}$ & $\begin{array}{l}\text { Poor metabolisers of CYP2D6 } \\
\text { Weight }<25 \mathrm{~kg} \\
\text { History of psychosis or seizure disorder } \\
\text { History of alcohol or drug abuse }\end{array}$ & ADHD-RS; CGI; CPRS & Spencer et $\left.a\right|^{22}$ \\
\hline $\begin{array}{l}\text { Randomised, } \\
\text { placebo controlled } \\
\text { study in adults; } \\
10 \text { weeks }\end{array}$ & $\begin{array}{l}\text { DSM-IV defined ADHD as assessed } \\
\text { by clinical interview and confirmed } \\
\text { by CAAR-D }\end{array}$ & $\begin{array}{l}\text { Major depression or anxiety disorder } \\
\text { Psychotic disorders } \\
\text { History of alcohol or drug abuse }\end{array}$ & $\begin{array}{l}\text { CAARS; CGI-S; } \\
\text { WRAADDS }\end{array}$ & Michelson et $a l^{17}$ \\
\hline $\begin{array}{l}\text { Once daily, } \\
\text { randomised, } \\
\text { placebo controlled } \\
\text { study in children; } \\
6 \text { weeks }\end{array}$ & $\begin{array}{l}\text { DSM-IV criteria; Investigator } \\
\text { administered and scored parent } \\
\text { version of ADHD Rating Scale IV }\end{array}$ & $\begin{array}{l}\text { Serious medical illness } \\
\text { History of psychosis } \\
\text { History of alcohol or drug abuse }\end{array}$ & $\begin{array}{l}\text { ADHD-RS; CGI; CPRS; } \\
\text { CTRS }\end{array}$ & Michelson et $a l^{13}$ \\
\hline $\begin{array}{l}\text { Once-daily } \\
\text { atomoxetine in } \\
\text { childhood ADHD: } \\
\text { continuous symptom } \\
\text { relief; weeks }\end{array}$ & $\begin{array}{l}\text { DSM-IV criteria; Investigator } \\
\text { administered and scored parent } \\
\text { version of ADHD Rating Scale IV }\end{array}$ & $\begin{array}{l}\text { Serious medical illness } \\
\text { History of psychosis or bipolar disorder } \\
\text { History of alcohol or drug abuse. }\end{array}$ & $\begin{array}{l}\text { ADHD-RS; DPREMB-R; } \\
\text { CGI-PE }\end{array}$ & Kelsey et $a l^{25}$ \\
\hline $\begin{array}{l}\text { Placebo controlled } \\
\text { study of once-daily } \\
\text { atomoxetine in the } \\
\text { school setting }\end{array}$ & $\begin{array}{l}\text { DSM-IV criteria; Investigator } \\
\text { administered and scored parent } \\
\text { version of ADHD Rating Scale IV }\end{array}$ & $\begin{array}{l}\text { Serious medical illness } \\
\text { Use of other psychotropic medication } \\
\text { Evidence of significant intellectual deficit }\end{array}$ & $\begin{array}{l}\text { ADHD-RS (teacher version); } \\
\text { APRS; BADDS }\end{array}$ & Weiss et $a l^{37}$ \\
\hline \multicolumn{5}{|c|}{$\begin{array}{l}\text { ADHD-RS, Attention Deficit Hyperactivity Disorder Rating Scale; }{ }^{19} \text { CAAR-D, Conners' Adult ADHD Diagnostic Interview for DSM-IV; }{ }^{21} \text { CPRS-R:S, Conners' Parent } \\
\text { Rating Scale-Revised: Short Version; CTRS, Conners' Teacher Rating Scale; }{ }^{24} \text { APRS, Academic Performance Rating Scale; WRAADDS, Wender-Reimherr Adult } \\
\text { Attention Deficit Disorder Scale; }{ }^{35} \text { ODD-RS, Oppositionally Defiant Disorder Rating Scale; }{ }^{36} \text { BADDS, Brown ADD Scales; BDI: Beck Depression Inventory; }{ }^{38} \\
\text { CAARS, Conners' Adult ADHD Rating Scale; CPRS, Conners' Parent Rating Scale; }{ }^{39} \text { CPRS-R, Conners' Parent Rating Scale-Revised; }{ }^{40} \text { CGI, Clinical Global } \\
\text { Impression; CGI-S, Clinical Global Impression-Severity of Illness; CGI-PE, Conners' Global Index-Parent Evening Scale; CHQ, Child Health Questionnaire; }{ }^{41} \\
\text { CDRS-R, Children's Depression Rating Scale Revised; DPREMB-R, Daily Parent Ratings of Evening and Morning Behaviours Revised; HARS, Hamilton Anxiety } \\
\text { Rating Scale; }{ }^{42} \text { HDRS, Hamilton Depression Rating Scale. }\end{array}$} \\
\hline
\end{tabular}

and only small changes in blood pressure and heart rate. ${ }^{30}$ The cardiovascular profile of atomoxetine, therefore, offers a distinct advantage over other noradrenergic agents, such as tricyclic antidepressants, with their associated cardiovascular burden. ${ }^{16}$

A placebo controlled study designed to compare the effects of abrupt discontinuation following acute treatment with atomoxetine in children, adolescents, and adults established that discontinuation of atomoxetine therapy did not result in the development of an acute discontinuation syndrome and was well tolerated. ${ }^{31}$

Because atomoxetine does not increase dopamine in the nucleus accumbens, a region associated with excitation and pleasurable behaviours, it is not expected to have abuse potential. ${ }^{72}$ This may make atomoxetine more acceptable. In addition, atomoxetine does not exacerbate tics $^{33}$ and it is potentially beneficial in patients with comorbid affective disorders. $^{8}$
ATOMOXETINE: CLINICAL INDICATIONS AND USES

On the basis of the evidence described above it would appear that atomoxetine is a viable alternative for the management of ADHD. In particular, its profile addresses the need to consider more than the immediate relief of symptoms and to take into account the quality of life of affected individuals and their families across their lifespan. Atomoxetine provides 24 hour a day symptom relief with once or twice daily dosing. As well as relieving core symptoms, treatment with atomoxetine is associated with significant improvement in the quality of life of the affected child and their family, and in child self esteem. An unexpected finding has been the effect of atomoxetine on sleep: children are reported to sleep better, improving their quality of life and that of their family. ${ }^{34}$ Atomoxetine does not appear to have any abuse potential, and so offers opportunities for treatment where substance misuse is an issue and also allows treatment without concern for potential black market value. 
ADHD can be a lifelong disorder and thus there is a need to consider the potential requirement for treatment across the lifespan. Atomoxetine has been shown to be effective in children, adolescents, and adults and therefore offers opportunities for continuity of treatment. It is licensed for children aged 6 years and above.

Height, weight, pulse, and blood pressure of children and young people receiving atomoxetine should be monitored on a regular basis. Contrary to recommendations for stimulants, patients administered atomoxetine should not have drug holidays because of the mechanism of action of the drug. The dose of atomoxetine is calculated on the basis of body weight with a recommended target dose of $1.2 \mathrm{mg} / \mathrm{kg}$. It is possible to increase this to $1.8 \mathrm{mg} / \mathrm{kg}$ if clinically indicated, but there are no safety and tolerability data for doses above this in children and young people. Atomoxetine administration with substrates of CYP2D6 and CYP3A does not result in clinically significant drug interactions. ${ }^{12}$

The development of atomoxetine represents an important advance in the pharmacological management of ADHD. In order to provide high quality individualised treatment to children, young people, and adults, clinicians require access to a range of drugs, thus allowing treatment to be matched to patient characteristics and preferences. There is therefore the need for further rigorously evaluated, licensed pharmacological interventions for the management of ADHD across the lifespan.

\section{REFERENCES}

1 Swanson JM, Kraemer HC, Hinshaw SP, et al. Clinical relevance of the primary findings of the MTA: success rates based on severity of ADHD and ODD symptoms at the end of treatment. J Am Acad Child Adolesc Psychiatry 2001;40:168-79.

2 Spencer T, Biederman J, Wilens T, et al. Pharmacotherapy of attention deficit hyperactivity disorder across the life cycle. J Am Acad Child Adolesc Psychiatry 1996;35:409-32.

3 Taylor E, Chadwick O, Hepinstall E, et al. Hyperactivity and conduct problems as risk factors of adolescent development. J Am Acad Child Adolesc Psychiatry 1996;35:1213-26.

4 Mannuzza S, Klein RG, Bonagura N, et al. Adult psychiatric status of hyperactive boys grown up. Am J Psychiatry 1998;155:493-8.

5 Kratochvil CJ, Vaughan BS, Harrington MJ, et al. Atomoxetine: a selective noradrenaline reuptake inhibitor for the treatment of attention-deficit/ hyperactivity disorder. Expert Opin Pharmacother 2003;4:1 165-74.

6 Faraone SV, Biederman J. Neurobiology of attention-deficit hyperactivity disorder. Biol Psychiatry 1998;44:951-8.

7 Bymaster FP, Katner JS, Nelson DL, et al. Atomoxetine increases extracellular levels of noradrenaline and dopamine in the prefrontal cortex of rat: a potential mechanism for efficacy in attention deficit/hyperactivity disorder Neuropsychopharmacology 2002;27:699-711.

8 Michelson D, Faries D, Wernicke J, et al. Atomoxetine in the treatment of children and adolescents with attention-deficity/hyperactivity disorder: a randomised, placebo-controlled, dose-response study. Pediatrics 2001; 108:1-9.

9 Sauer JM, Ponsler GD, Mattiuz EL, et al. Disposition and metabolic fate of atomoxetine hydrochloride: the role of CYP2D6 in human disposition and metabolism. Drug Metab Dispos 2003;31:98-107.

10 Kratochvil CJ, Heiligenstein JH, Dittmann R, et al. Atomoxetine and methylphenidate treatment in children with ADHD: a prospective, randomised, open-label trial. J Am Acad Child Adolesc Psychiatry 2002;41:776-84.

11 Belle DJ, Ernest CS, Sauer JM, et al. Effect of potent CYP2D6 inhibition by paroxetine on atomoxetine pharmacokinetics. J Clin Pharmacol 2002;42:1219-27.

12 Sauer JM, Long AJ, Ring B, et al. Atomoxetine hydrochloride: clinical drugdrug interaction prediction and outcome. J Pharmacol Exp Ther 2004;308:410-18.

13 Michelson D, Allen A, Busner J, et al. Once daily atomoxetine treatment for children and adolescents with attention deficit hyperactivity disorder: a randomised, placebo controlled study. Am J Psychiatry 2002;159:1896-901.

14 Spencer T, Biederman J, Wilens T, et al. Effectiveness and tolerability of tomoxetine in adults with attention deficit hyperactivity disorder. Am J Psychiatry 1998; 155:693-5.
15 Kratochvil CJ, Bohac D, Harrington $M$, et al. An open-label trial of tomoxetine in pediatric attention deficit hyperactivity disorder. J Child Adolesc Psychopharmacol 2001;11:167-70.

16 Spencer T, Biederman J, Heiligenstein $\mathrm{JH}$, et al. An open-label, dose-ranging study of atomoxetine in children with attention deficit hyperactivity disorder. J Child Adolesc Psychopharmacol 2001;11:251-65.

17 Michelson D, Adler L, Spencer T, et al. Atomoxetine in adults with ADHD: Two randomized, placebo-controlled studies. Biol Psychiatry 2003:53:112-20.

18 Kaufman J, Birmaher B, Brent D, et al. Kiddie-SADS Present and Lifetime Version (K-SADS-PL), Version 1.0, October 1996. Pittsburgh, PA: Department of Psychiatry, University of Pittsburgh School of Medicine, 1996.

19 DuPaul GJ, Power TJ, Anastopoulos AD, et al. ADHD Rating Scale-1V: checklists, norms and clinical interpretations. New York: Guilford Press, 1998.

20 Guy W, ed. ECDEU assessment manual for psychopharmacology. Washington DC: US Department of Health, Education and Welfare, 1976, Publication No ADM 76-338.

21 Conners CK. Clinical use of rating scales in the diagnosis and treatment of attention-deficit/hyperactivity disorder. Pediatr Clin North Am 1999;46:857-70

22 Spencer T, Heiligenstein JH, Biederman J, et al. Results of two proof-ofconcept, placebo-controlled studies of atomoxetine in children with attentiondeficit/hyperactivity disorder. J Clin Psychiatry 2002;63:1140-7.

23 Biederman J, Heiligenstein JH, Faries DE, et al. Efficacy of atomoxetine versus placebo in school-age girls with attention-deficit/hyperactivity disorder. Pediatrics 2002;110:e75.

24 Conners CK. Conners' rating scales: revised technical manual. North Towanda, NY: Multi-Health Systems, 1997.

25 Kelsey D, Summer C, Casat C, et al. Once-daily atomoxetine in childhood ADHD: continuous symptom relief. Poster presented at the 50th Annual Meeting of the American Academy of Child \& Adolescent Psychiatry. Florida: Miami, 14-19 October, 2003

26 Barton J, Prasad S, Buitelaar JK, et al. 10-week open-label acute treatment in non-North American children with ADHD. Poster presented at the Royal College of Psychiatrists Annual General Meeting, Scotland: Edinburgh, 30 June-3 July, 2003.

27 Harpin V, Prasad S, Michelson D. Atomoxetine in the long-term prevention of relapse of ADHD. Paper presented at the Royal College of Paediatrics and Child Health Annual Spring Meeting, 29 March, 2004.

28 Wernicke J, Newcorn JH, Casat C, et al. Atomoxetine and methylphenidate treatment in children with ADHD: A prospective, randomised, open-label trial. J Am Acad Child Adolesc Psychiatry 2002;41:776-84.

29 Wernicke JF, Kratochvil CJ. Safety profile of atomoxetine in the treatment of children and adolescents with ADHD. J Clin Psychiatry 2002;63(Suppl 12):50-5.

30 Wernicke JF, Faries D, Girod D, et al. Cardiovascular effects of atomoxetine in children, adolescents and adults. Drug Saf 2003;26:729-40.

31 Wernicke JF, Adler L, Spencer T, et al. Changes in symptoms and adverse events after discontinuation of atomoxetine in children and adults with attention deficit/hyperactivity disorder: a prospective, placebo-controlled assessment. J Clin Psychopharmacol 2004;24:30-5.

32 Heil SH, Holmes HW, Bickel WK, et al. Comparison of the subjective physiological, and psychomotor effects of atomoxetine and methylphenidate in light drug users. Drug Alcohol Depend 2002;67:149-56.

33 McCracken JT, Sallee R, Leonard HL, et al. Improvement of ADHD by atomoxetine in children with tic disorders. Presented at the 50th Annual Meeting of the American Academy of Child \& Adolescent Psychiatry, Florida: Miami, 14-19 October, 2003, Abstract B28.

34 Sangal RB, Owens J, Allen AJ, et al. Effects of Atomoxetine and Methylphenidate on Sleep in Children with ADHD. Poster presented at the Associated Professional Sleep Societies Meeting, Philadelphia: June, 2004.

35 Wender PH, Reimherr FW, Wood D, et al. A controlled study of methylphenidate in the treatment of attention deficit disorder, residual type, in adults. Am J Psychiatry 1985;142:547-52.

36 Barkley RA. Attention deficit/hyperactivity disorder: A handbook for diagnosis and treatment. 2nd ed. New York: Guilford Press, 1998.

37 Weiss M, Tannock R, Kratochvil C, et al. Placebo-controlled study of oncedaily atomoxetine in the school setting. Eur Neuropsychopharmacol 2003; 13:S456

38 Beck AT, Ward CH, Mendelson M, et al. An inventory for measuring depression. Arch Gen Psychiatry 1961;4:561-71.

39 Conners CK. Rating scales for use in drug studies with children. Psychopharmacol Bull 1973;9:24-9.

40 Conners CK, Parker JDA, Sitarenios G, et al. The Revised Conners' Parent Rating Scale (CPRS-R): Factor structure, reliability, and criterion validity. J Abnorm Child Psychol 1998;26:257-68.

41 Landgraf JM, et al. The Child Health Questionnaire (CHQ): A user's manual. Boston: The Health Institute, New England Medical Center, 1996.

42 Hamilton M. The assessment of anxiety states by rating. Br J Med Psychol 1959:32:50-5.

43 Hamilton M. Development of a rating scale for primary depressive illness. Br J Soc Clin Psychol 1967;6:278-96. 